\title{
Syndrom Piotrusia Pana jako PrZyczyna psychiczna NIEZDOLNOŚCI DO MAŁŻEŃSTWA W PRAKTYCE SĄDU Metropolitalnego w Lublinie
}

\section{Wstęp}

Na przestrzeni ostatnich dziesięcioleci średnia wieku osób zawierających małżeństwo znacznie się podwyższyła. Ma na to wpływ wiele czynników, zwłaszcza że odpowiedź na pytanie, jaki jest najlepszy czas na wstąpienie $\mathrm{w}$ związek małżeński i założenie rodziny nie jest prosta. Wydaje się bezdyskusyjne, że małżeństwo można zawierać wtedy, gdy jest się do niego dojrzałym ${ }^{1}$, dojrzałość zaś jest indywidualną cechą każdego człowieka, na którą składają się różne aspekty i która nie może zostać określona w sposób jednolity dla wszystkich².

Ogólnie można stwierdzić, że na dojrzałość składa się z jednej strony zdolność do podejmowania ról oraz umiejętność ukierunkowania swojego zachowania i brania za nieodpowiedzialności, z drugiej zaś dojrzałość wyrażają cechy sprzyjające rozwojowi osobistemu (jak samoocena czy samoakceptacja $)^{3}$. Niezależnie jednak od tego, na co przy określaniu dojrzałości będ zie się kładło nacisk, kojarzyć się z nią będzie pojęcie dorosłości. Dorosłość z kolei łączy się z umiejętnością podejmowania i realizowania

* Dr, Katolicki Uniwersytet Lubelski Jana Pawła II, wiceoficjał Sądu Metropolitalnego w Lublinie; e-mail: grzegorz.bzdyrak@kul.pl, https:/ / orcid.org/0000-0003-1751-4318.

1 M. Braun-Gałkowska, Psychologia domowa, Lublin 2008, s. 100.

2 Na temat kanonicznych aspektów określenia osobowości dojrzałej zob. S. Paździor, Przyczyny psychiczne niezdolności osoby do zawarcia matżeństwa w świetle kan. 1095 n. 3, Lublin 2009, s. 71-78.

3 Zob. P. Oleś, Psychologia człowieka dorosłego, Warszawa 2011, s. 258-259. 
długofalowych dążeń poprzez wybór określonej linii życia. Co więcej, dorosłość to stałe branie odpowiedzialności za siebie i innych, połączone jednocześnie ze świadomością ewentualnych skutków. To także niezależność emocjonalna i samodzielność w podejmowaniu decyzji ${ }^{4}$.

W związku z taką wizją dorosłości coraz więcej osób stara się wkroczyć w nią jak najpóźniej, a niekiedy nawet wcale nie pragnie jej osiągnąć. Współcześnie to zjawisko określać można pojęciem dorosłości odroczonej ${ }^{5}$, terminem kidults ${ }^{6}$ czy syndromem Piotrusia Pana. Najczęściej syndrom Piotrusia Pana dotyka mężczyzn, jednak niewykluczone, na co wskazuje praktyka sądowa, iż tego typu zaburzenie może pojawić się również u kobiet.

\section{Syndrom Piotrusia Pana jako zaburzenie psychiczne}

Twórcą pojęcia i głównym badaczem syndromu Piotrusia Pana jest amerykański psycholog Dan Kiley, który swoje badania i przemyślenia na ten temat przedstawił w książce pod znaczącym tytułem Syndrom Piotrusia Pana. O nigdy nie dojrzewajacych mężczyznach ${ }^{7}$.

Piotruś Pan, główny bohater powieści Jamesa Matthew Barriego, to mały chłopiec, którego marzeniem było pozostanie dzieckiem na zawsze. Jego pragnienie niekończącej się zabawy, bez odpowiedzialności i obowiązków, było tak silne, że rzeczywiście Piotruś nigdy nie dorósł. Pozostał

4 Zob. tamże, s. 17-19.

5 Pojęcie dorosłości odroczonej odnosi się do młodych ludzi, którzy są niezdolni do realizowania zadań związanych z dorosłością; zjawisko to tłumaczone jest kultem młodości i zabawy oraz niedojrzałością emocjonalną młodych ludzi, zob. M. Wnuk, W poszukiwaniu „dorosłości”, Dyskursy Młodych Andragogów 2007, nr 8, s. 24.

6 Angielskie słowo kidults składa się z dwóch słów: kid - dziecko i adult - dorosły. Termin ten po raz pierwszy został użyty w 1985 r. na łamach „The New York Times”. Jego autor, Peter Martin, zastosował go na określenie ludzi z jednej strony korzystających z doświadczeń dorosłości, a jednocześnie uciekających, na wzór dzieci, od jej trudów i zobowiązań. Kidults to dorośli, którzy usiłują powrócić do bezpiecznych lat dziecięcych i szczęśliwej nieświadomości, pod wieloma względami (poglądów i postaw) kryjący w sobie niechęć do dorosłości, zob. J. Mazur, Oblicze fenomenu kidults, Tarnowskie Studia Teologiczne 2016, t. 35, nr 2, s. 41.

7 D. Kiley, Syndrom Piotrusia Pana. O nigdy nie dojrzewających mężczyznach, Warszawa 1993. 
małym chłopcem, niedojrzałym do założenia rodziny oraz podjęcia obowiązków wiążących się z samodzielnym życiem.

Pierwszym z sygnałów świadczących o syndromie Piotrusia Pana będzie rozbieżność pomiędzy wiekiem a dojrzałością. Jak twierdzi D. Kiley, życie osoby obciążonej syndromem Piotrusia Pana jest zdominowane przez siedem cech psychologicznych: zablokowanie emocji - emocje są stłumione, a sposób ich przeżywania nie odpowiada ich uzewnętrznianiu; odwlekanie decyzji - osoby młode próbują odwlekać różne sprawy do momentu, kiedy jakaś absolutna konieczność nie zmusi ich do działania, a ich cele życiowe są przy tym mgliste i nieokreślone; niewydolność społeczna - pomimo starań człowiek nie jest w stanie znaleźć sobie prawdziwych przyjaciół, choć pragnie gdzieś przynależeć, ponieważ jest przeraźliwie samotny i panicznie boi się skazania wyłącznie na siebie; myślenie magiczne - myślowe prestidigitatorstwo pozwala uniknąć uczciwego przyznania się do błędów, a opanowane do perfekcji obwinianie innych za własne niedociągnięcia często chroni przed koniecznością radzenia sobie z niewydolnością społeczną i zablokowanymi emocjami; odrzucenie matki - synowie dotknięci syndromem Piotrusia Pana z jednej strony pragną uwolnić się spod wpływu matki, z drugiej jednak, gdy próbują to robić, czują się winni; odrzucenie ojca - Piotruś Pan czuje się odtrącony przez ojca i chociaż marzy o jego bliskości, to jednocześnie postanawia nigdy nie przyjmować jego miłości i aprobaty; odrzucenie seksu - objawy niewydolności społecznej przenoszą się również na życie seksualne, przy czym lęk przed odrzuceniem sprawia, że osoba z syndromem Piotrusia Pana pragnie skryć swoją wrażliwość pod maską "okrutnego i bezdusznego macho", który w pewnym momencie może popaść w inną skrajność: odbywać stosunki z każdą chętną kobietą, udowadniając samemu sobie swoją potencję, jednak jeśli zdecyduje się na jedną partnerkę, uzależnia się od niej całkowicie, o ile partnerka nie wykazuje cech stanowczości i niezależności ${ }^{8}$.

Mężczyzna jednakże „staje się ofiarą syndromu Piotrusia Pana dopiero wtedy, gdy objawy zaczynają zakłócać jego codzienne życie i rozwój normalnych stosunków z innymi ludźmi" ${ }^{\prime \prime}$. Do wspomnianych objawów - jak twierdzi w swojej pracy znawca tematu, D. Kiley - należą zaś: nieodpowiedzialność, niepokój, osamotnienie, konflikt ról seksualnych,

\footnotetext{
8 Zob. tamże, s. 17-19.

9 Tamże, s. 22.
} 
narcyzm oraz męski szowinizm. Nieodpowiedzialność jest niejako kluczem do pozostania młodym. To cecha dzieciństwa. Niemniej w sytuacji gdy rodzice wychowują dziecko, nie korzystając ze swojej władzy i nie nakładając ograniczeń swobodnego rozwoju dziecka, sami przyczyniają się do rozwoju u niego postawy nieodpowiedzialności. Dziecko uważa wówczas, że pewne zasady go nie obowiązują i w przyszłości nie będzie w stanie przyswoić sobie podstawowych nawyków i obowiązków. W dorosłości odpowiedzialność jest codziennym nawykiem, od którego nie sposób się uwolnić. Tymczasem osoby z syndromem Piotrusia Pana nie mogą uciec od nieodpowiedzialności ${ }^{10}$. Innym objawem jest niepokój. Często jest on zapoczątkowany i umacniany przez problemy małżeńskie rodziców, którzy w pewnym momencie, w takim czy innym stopniu, tracą kontakt ze swoimi dziećmi. Ponadto w większości przypadków rodzice starają się utrzymać pozory rodzinnego szczęścia. Stwarza to jednak atmosferę napięcia, które dzieci wyczuwają, towarzyszy im ono również w późniejszym życiu ${ }^{11}$. Współcześnie także zamiast poświęcać czas dzieciom, rodzice przekazują im pieniądze, nie ucząc jednak, że należy je zarobić. Mając więc zapewnione podstawowe potrzeby, młodzi ludzie mogą skupić się na poszukiwaniu coraz to nowych rozrywek oraz grup, do których mogliby przynależeć, gdyż brak zainteresowania i troski ze strony rodziców potęguje $\mathrm{w}$ nich poczucie osamotnienia. I mimo że starają się unikać odrzucenia, to często z uwagi na niewystarczające zaangażowanie ich relacje są bardzo powierzchowne ${ }^{12}$. Kolejny objaw - konflikt ról seksualnych - pojawia się w chwili, gdy młody człowiek jest rozdarty na dwie strony: z jednej pociąg seksualny kieruje chłopca ku kontaktom z dziewczętami, z drugiej zaś, przez brak poczucia bezpieczeństwa, jak dziecko chroni się "za matczyną spódnicę". Lęk przed niepowodzeniem albo odrzuceniem uniemożliwia osobie z syndromem Piotrusia Pana podjęcie ryzyka i prawdziwe zaangażowanie się w związek uczuciowy ${ }^{13}$. Na odgrywanie roli dorosłego, a przez to oczekiwanie akceptacji pozwala Piotrusiowi narcyzm, który jest następnym wspomnianym objawem. Ten szczególny rodzaj zachwytu nad sobą wydaje się chronić przed rozczarowaniami i problemami. Uwidacznia się on jednak jako niebezpieczny

\footnotetext{
10 Szerzej tamże, s. 43-57.

11 Szerzej tamże, s. 58-77.

12 Szerzej tamże, s. 78-88.

13 Szerzej tamże, s. 89-103.
} 
rozdźwięk pomiędzy wyobrażeniami a rzeczywistością, przyczyniając się do tworzenia systemu rozumowania i postępowania całkowicie odpornego na krytykę ${ }^{14}$. Ostatni objaw syndromu Piotrusia Pana to męski szowinizm. Odbiega on jednak $\mathrm{w}$ tym przypadku od typowego wzorca, będąc bardziej wyrafinowanym i podstępnym. Jest on często reakcją na oznaki braku wiary w siebie i sposobem udawania bycia dorosłym. Uprzedzenia Piotrusiów stają się też przejawem mądrości. Narcyzm i szowinizm w połączeniu wywołują zaś postawę egoistyczną, która swoją podstawę ma w samozakłamaniu ${ }^{15}$.

\section{Syndrom Piotrusia Pana a podjęcie i wypełnienie istotnych obowiązków małżeńskich}

W kan. 1095 n. 2 i 3 KPK $1983^{16}$ prawodawca kodeksowy wskazuje, że „niezdolni do zawarcia małżeństwa są ci, którzy dotknięci są poważnym brakiem rozeznania oceniającego co do istotnych praw i obowiązków małżeńskich” (kan. 1095 n. 2 KPK 1983) oraz „z przyczyn natury psychicznej nie są zdolni do podjęcia i wypełnienia istotnych obowiązków małżeńskich" (kan. 1095 n. 3 KPK 1983). Rozpatrując zdolność do małżeństwa osoby dotkniętej syndromem Piotrusia Pana, należy więc w pierwszej kolejności wskazać, jakie obowiązki małżeńskie są istotne, a jakie nie. Jest to o tyle ważne, że Piotruś Pan może bardzo dobrze radzić sobie na polu zawodowym, piąć się po szczeblach kariery, piastować wysokie stanowiska i pobierać duże wynagrodzenie, być osobą towarzyską i lubianą, a więc z pozoru stanowić dobrego kandydata na męża lub żonę. Jednak realizując tylko nieistotne z prawnego punktu widzenia obowiązki małżeńskie, nadal będzie niezdolny do ważnego zawarcia małżeństwa.

Kodeks nie wskazuje wprost, jakie obowiązki małżeńskie są istotne, dlatego też w tym zakresie należy odwołać się do doktryny i praktyki orzeczniczej. Szczegółowej analizy istotnych obowiązków małżeńskich

14 Szerzej tamże, s. 104-114.

15 Szerzej tamże, s. 115-122.

16 Codex Iuris Canonici auctoritate Ioannis Pauli PP. II promulgatus (25.01.1983 r.), Acta Apostolicae Sedis (dalej AAS) 75(1983), pars II, s. 1-317. Kodeks prawa kanonicznego, przekład polski zatwierdzony przez Konferencję Episkopatu, Poznań 1984 (dalej: KPK 1983). 
wynikających z bonum prolis oraz bonum coniugum dokonali przede wszystkim ks. prof. Wojciech Góralski ${ }^{17}$ i ks. prof. Ryszard Sztychmiler ${ }^{18}$. Jak wskazuje R. Sztychmiler, do obowiązków małżeńskich należy zaliczyć te, które warunkują realizację bonum prolis i bonum coniugum. Obowiązki te wzajemnie się przenikają, gdyż nie ma obowiązków, które służyłyby wyłącznie dobru potomstwa, a jednocześnie nie służyły dobru małżonków. Do obowiązków służących realizacji dobra małżonków należą: obowiązek zachowania wierności małżeńskiej, obowiązek ludzkiego pożycia intymnego ze współmałżonkiem, obowiązek zachowania dozgonnego charakteru małżeństwa, obowiązek zachowania prawidłowych małżeńskich relacji interpersonalnych, obowiązek przyczyniania się do dobra współmałżonka i świadczenia mu pomocy, obowiązek świętości. Z bonum prolis wynika zaś obowiązek pożycia intymnego zmierzającego do zrodzenia potomstwa oraz obowiązek przyjęcia potomstwa poczętego ${ }^{19}$.

Syndrom Piotrusia Pana przede wszystkim wiąże się z postawą charakteryzującą się ucieczką od dorosłości, brakiem dojrzałości i unikaniem wszelkiej odpowiedzialności. Cechuje on ludzi z jednej strony żądnych wolności i odważnych w obliczu niebezpieczeństw, z drugiej zaś panicznie bojących się dorastania i przyjęcia na siebie obowiązków oraz odznaczających się samotnością, narcyzmem czy niezdolnością do tworzenia dojrzałych relacji z ludźmi ${ }^{20}$. Osoby dotknięte syndromem Piotrusia Pana chcą robić wszystko, na co przyjdzie im ochota, nie licząc się przy tym z konsekwencjami i nie chcąc ich ponosić. Co więcej, osoby takie nie są w stanie nawiązywać i utrzymywać stosunków z innymi ludźmi, nie potrafią tworzyć i być w prawdziwych relacjach międzyosobowych. W konsekwencji, mając problemy z podtrzymywaniem pozytywnych relacji małżeńskich, uciekają od decyzji o zakładaniu własnej rodziny ${ }^{21}$. Egocentryzm, jaki charakteryzuje osoby z syndromem Piotrusia Pana, nie pozwala im na opanowanie umiejętności zachowywania się w sposób empatyczny,

17 Zob. W. Góralski, Kanoniczna zgoda matżeńska, Gdańsk 1991; W. Góralski, Dobro matżonków a istotne obowiązi małżeńskie, Warszawa 2010.

18 Zob. R. Sztychmiler, Istotne obowiązi matżeńskie w Kodeksie Prawa Kanonicznego z 1983 roku, Roczniki Nauk Prawnych 1997, t. 7, s. 121-138; R. Sztychmiler, Istotne obowiazki matżeńskie, Warszawa 1997; R. Sztychmiler, Obowiązki małżeńskie, Warszawa 1999.

19 R. Sztychmiler, Obowiązki małżeńskie, s. 244-260.

20 Zob. Z. Miłuński, Piotruś Pan i jego szpan, Charaktery 2006, nr 10, s. 10-15.

21 Zob. J. Kargul, "Piotruś Pan” $i$ "Wieczna Dziewczynka” - w kalejdoskopie odraczania dorosłości, Edukacja Dorosłych 2017, nr 1, s. 23. 
a przez to na wsłuchiwanie się w narrację drugiej osoby. Nie ucząc się funkcjonowania we wspólnocie, nie widzą konieczności zwracania uwagi na potrzeby innych. W związku z tym, przebywając z ludźmi, Piotruś Pan cały czas będzie dbał o ochronę własnego ",ja" oraz o zaspokojenie swoich celów i pragnień, uważając, że to inni powinni przystosować się w pełni do jego oczekiwań ${ }^{22}$. Właściwe relacje interpersonalne są poważnym problemem w syndromie Piotrusia Pana. Ich powierzchowne traktowanie spowodowane jest bowiem obawą przed podejmowaniem odpowiedzialności i kreśleniem planów na przyszłość. Przyjaźń dla współczesnego Piotrusia Pana ma cechy charakterystyczne dla przyjaźni dziecięcej. Opiera się więc przede wszystkim na wspólnym spędzaniu czasu i wykonywaniu tych samych czynności. Podobieństwo oczekiwań i zainteresowań oraz zaspokajanie pragnień i potrzeb warunkują długość trwania przyjaźni. Tym samym przyjaźń trwa, dopóki zyski z relacji są większe niż straty. Jeżeli jednak zasady, którymi kierują się przyjaciele, zaczną się oddalać od przekonań Piotrusia Pana, przyjaźń z jego strony ustaje ${ }^{23}$. Podobny schemat można zauważyć w relacji do partnera. Związek trwa do momentu, gdy odpowiada wyobrażeniom Piotrusia Pana. Jeżeli druga osoba zaczyna stawiać mu jakieś wymagania, oczekiwać czegoś czy dążyć do innych celów, następuje rezygnacja z relacji. Człowiek z syndromem Piotrusia Pana spodziewa się bowiem ze strony partnera akceptacji i aprobaty jego zachowań, a nie podejmowania obowiązków i odpowiedzialności - a więc zachowania charakterystycznego bardziej dla opiekunczej matki niż żony ${ }^{24}$.

W obecnych czasach młodzi ludzie są z wielu stron otaczani przekazem sugerującym im, że wszystko zależy od nich samych, że mogą w dowolny sposób się rozwijać, korzystać z bogactwa własnej osobowości, mieć szeroki wybór i konstruować życie wyłącznie według swojej indywidualnej wizji. U progu dorosłości mogą sami decydować o wszystkim. Nie jest to jednak łatwe, ponieważ nikt nie uczy ich odpowiedzialności za podejmowane decyzje ${ }^{25}$. Najlepszą drogą wydaje się więc dla nich ucieczka od dorosłości. Tym bardziej, że poza wiążącą się z nią odpowiedzialnością, dorosłość dla osób z syndromem Piotrusia Pana to nuda i stagnacja.

\footnotetext{
22 Zob. tamże, s. 30.

23 Zob. J. Mazur, Oblicze fenomenu kidults, s. 44.

24 Zob. D. Kiley, Syndrom Piotrusia Pana..., s. 67.

25 Zob. J. Kargul, „Piotruś Pan” $i$ „Wieczna Dziewczynka”..., s. 26.
} 
Życie kojarzące się z dzieciństwem i młodością, a także przyjemnością traktowaną priorytetowo powinno się sprowadzać do radości i rozrywki. Osłabienie czy w ogóle zanik jakichkolwiek obowiązków, ciągła chęć zabawy, potrzeba oderwania się od codzienności są konsekwencją stawiania na pierwszym miejscu swojego własnego dobrego samopoczucia i własnych korzyści. Piotruś Pan będący indywidualistą ma zatem problemy ze sprostaniem wymaganiom życia społecznego i dostosowaniem swojego życia do własnych wyobrażeńen ${ }^{26}$.

Do wykształcenia tych wszystkich cech charakterystycznych dla osób dotkniętych syndromem Piotrusia Pana przyczynia się bardzo często nieobecność ojca w procesie wychowawczym ${ }^{27}$. We współczesnym modelu rodziny nierzadko brakuje męskiego wzorca, czego przyczyną są coraz częstsze rozwody, jak również mocno wydłużające się godziny pracy i związana z tym nieobecność męża i ojca w domu. Nie bez znaczenia pozostaje także migracja zarobkowa, skutkująca rozłąką w życiu rodziny, widywaniem ojca kilka dni w roku, kiedy to czas poświęcony jest głównie na rozrywkę. Ojciec postrzegany jest jako osoba niebiorąca udziału w wychowaniu dziecka, bierna wobec jego problemów. Rola ojca często sprowadzona jest wyłącznie do zapewnienia materialnego bytu rodzinie, a nie uczestniczenia w jej życiu. Negatywna relacja z ojcem wywołuje zaś skutki w dorosłym życiu każdego człowieka ${ }^{28}$. Brak wpływu ojca na wychowanie i rozwój może powodować chociażby zahamowanie rozwoju emocjonalnego i moralnego, niskie poczucie bezpieczeństwa czy problemy z nawiązywaniem relacji i przystosowaniem się do życia w społeczeństwie $^{29}$. Wychowywanie chłopca tylko przez matkę, która poświęca się dla niego całkowicie i wyręcza go we wszystkim, tworzy między nimi relację opartą na uzależnieniu. Matka staje się najważniejszą kobietą w życiu, za którą chłopiec, a później mężczyzna staje się odpowiedzialny. Nie potrafi on w konsekwencji nawiązać prawdziwej i głębokiej relacji z inną kobietą. Bliski kontakt z ojcem stanowi natomiast istotne podłoże funkcjonowania młodego chłopca w dorosłym życiu. Relacje oparte na zaufaniu i akceptacji ze strony ojca, a także wymiana uczuć, doświadczeń i przeżyć

26 Zob. J. Mazur, Oblicze fenomenu kidults, s. 46.

27 Zob. E. Badinter, XY tożsamość mężczyzny, Warszawa 1993, s. 78.

28 Zob. A. Bzymek, Piotrusia Pana droga do ojca, w: Oblicza teorii i praktyki oświatowo-wychowawczej w czasie i przestrzeni, red. T. Maliszewski, J. Żerko, Gdańsk 2014, s. 123.

29 Zob. K. Pospiszyl, O miłości ojcowskiej, Warszawa 1976, s. 54-55. 
oraz wspieranie i zachęcanie syna do tworzenia relacji interpersonalnych i podejmowania odpowiedzialności prowadzą do prawidłowego rozwoju społecznego, ułatwiając wkroczenie $\mathrm{w}$ dorosłość ${ }^{30}$.

Osoba dotknięta syndromem Piotrusia Pana nie jest tym samym w stanie podjąć i wypełnić istotnych obowiązków małżeńskich wynikających $\mathrm{z}$ bonum prolis i bonum coniugum. Może realizować $\mathrm{z}$ powodzeniem wiele innych obowiązków, które służą tworzeniu szczęśliwego małżeństwa, ale są uznawane na gruncie prawa kanonicznego za nieistotne, a tym samym za niemające znaczenia prawnego.

\section{Syndrom Piotrusia Pana - doświadczenia Sądu Metropolitalnego w Lublinie}

Analiza akt sądowych dotyczących stwierdzenia nieważności małżeństwa pozwala na konkluzję, że coraz częściej przyczyną nieważności małżeństw jest już nie tylko niedojrzałość osobowościowa czy głęboka niedojrzałość, ale niedojrzałość sklasyfikowana jako syndrom Piotrusia Pana. Mimo że analizie poddano akta spraw toczących się od 1983 r., to tak naprawdę o syndromie Piotrusia Pana biegli zaczęli wspominać wprost dopiero w sprawach toczących się po 2010 r. Najczęściej jednak zachowania charakterystyczne dla syndromu Piortusia Pana opisywali jako zaburzenie osobowości - głęboką niedojrzałość osobowościową.

W sprawie toczącej się przed Sądem Metropolitalnym w Lublinie w 2015 r. biegła wprost wskazała, że przyczyną braku skutecznego realizowania obowiązków małżeńskich była osobowość zaburzona z syndromem Piotrusia Pana. Pozwany nie brał udziału w procesie, ale bardzo istotny wpływ na treść opinii psychologicznej miały zeznania jego matki, która jako świadek w sprawie wskazała, że sama widziała brak dojrzałości syna do małżeństwa i przeczuwała, że może to być "tylko taka zabawa na moment". Pozwany, choć wychowywał się w pełnej rodzinie, doświadczył wzoru „ojca nieobecnego", gdyż jego ojciec wyjechał za granicę na kilka lat. Jako młody chłopak zaczął sprawiać problemy wychowawcze. Strony bardzo szybko zamieszkały ze sobą i to powódka przejęła na siebie wszystkie obowiązki związane z codziennym funkcjonowaniem.

\footnotetext{
30 Zob. A. Bzymek, Piotrusia Pana droga do ojca, s. 127.
} 
Dobrze zarabiała i spełniała wszelkie zachcianki pozwanego - kupowała mu drogie, markowe ubrania, gadżety. Kiedy straciła pracę i pojawiły się problemy finansowe, pozwany nie potrafił ograniczyć swoich potrzeb, a powódka, nie chcąc sprawiać mu przykrości, zapożyczała się lub zadłużała mieszkanie. Pozwany egoistycznie skupiał się jedynie na swoich potrzebach, nie myślał o wspólnocie małżeńskiej. Powódka bardzo szybko przekonała się, że pozwany ma zupełnie inną wizję małżeństwa i różnią się oni wyznawaną hierarchią wartości. Pozwany nie chciał mieć potomstwa, ponieważ traktował mogące się pojawić dziecko jako zagrożenie dla swojej wolności. Nie lubił się również dzielić i nawet możliwość zjedzenia całej czekolady samemu sprawiała mu radość. Nie czuł się odpowiedzialny pod względem finansowym, skupiał się na realizacji swoich celów, prowadził rozrywkowy tryb życia. Biegła zauważyła, że cechy funkcjonowania pozwanego $\mathrm{w}$ znacznym stopniu odpowiadają charakterystyce osobowości niedojrzałej, w pewien sposób zaburzonej, opisanej w psychologii jako osobowość z syndromem Piotrusia Pana. Pozwany uciekał od odpowiedzialności i prawdziwego życia w świat fantazji oraz idealizmu, był lekkomyślny, poszukiwał przygód (w tym erotycznych), nie potrafił planować przyszłości, przerzucał odpowiedzialność i konieczność podejmowania wiążących decyzji na inne osoby. Przyczynę ukształtowania takiej osobowości pozwanego biegła upatruje we wzrastaniu pozwanego bez właściwego wzorca męskiego w domu rodzinnym ${ }^{31}$.

Podobne cechy osobowości - jednak tym razem w odniesieniu do kobiety - biegła zauważyła w sprawie toczącej się przed Sądem Metropolitalnym w Lublinie w 2017 r. Jest to jedyny przypadek sprawy z badanego okresu, gdy przejawy osobowości zaburzonej z syndromem Piotrusia Pana zdiagnozowano u kobiety. Również tutaj przyczynę ukształtowania takiej osobowości pozwanej biegła upatrywała w rodzinie pochodzenia. Pozwana już w chwili nawiązywania bliższej relacji z powodem, mimo swojego wieku (23 lata), była traktowana przez rodziców jak nastolatka, której nie obdarza się zaufaniem. Nawet w trakcie procesu swoim zachowaniem wykazała, że wsparcie rodziców jest dla niej najważniejsze. Ujawniła trudności w samodzielnym działaniu. Atmosfera, w jakiej wychowywała się pozwana, była trudna i napięta. Nadmiernie wymagający rodzice oczekiwali od córki zbyt wiele, nie uznawali jej za równego

31 Archiwum Sądu Metropolitalnego Lubelskiego (dalej: ASML), sygn. 8069/2015/ I instancja. 
członka rodziny i nie szanowali jej indywidualności. Nie przyznawali jej prawa do samodzielności, uniemożliwiali działania na własną odpowiedzialność, nie dopuszczali możliwości odstępstw od ustalonych przez nich zasad. Takie postawy rodzicielskie wytworzyły u niej brak wiary we własne siły, niepewność, lękliwość i stałą potrzebę korzystania z pomocy rodziców. Pozwana $\mathrm{w}$ trakcie trwania małżeństwa często kontaktowała się z rodzicami, spędzała z nimi wiele czasu, miała trudności z podejmowaniem codziennych decyzji i w tym zakresie to u rodziców szukała wsparcia. Sama wykazywała się egocentryzmem, miała niską odporność na sytuacje trudne, ciągle oczekiwała gratyfikacji ${ }^{32}$.

Również w roku 2015 toczyła się sprawa, w której biegły zdiagnozował u pozwanego niedojrzałość osobowościową przejawiającą się w różnym stopniu natężenia głębokim egocentryzmem, powierzchownością uczuciowo-emocjonalną, nieodpowiedzialnością, instrumentalnym traktowaniem rzeczywistości i innych osób, deficytem $\mathrm{w}$ zakresie samodzielnego podejmowania decyzji. Ponadto dostrzegł u pozwanego objawy syndromu Piotrusia Pana charakteryzującego się ucieczką od dorosłości oraz unikaniem zobowiązań. Według biegłego „Piotruś Pan to żądny przygód marzyciel, chłopiec skupiony na sobie, niezdolny do budowania trwałych więzi, oczekujący od swojej partnerki postawy matkującej”. Pomiędzy stronami już w okresie przedmałżeńskim dochodziło do licznych nieporozumień, choć tłumaczyli to różnicami charakterów. Wtedy jednak nie postrzegali tego jako niebezpieczeństwo dla przyszłego związku, ale uznawali zasadę, że "przeciwieństwa się przyciągają", co świadczy o ich naiwności życiowej i łatwowierności. W ich związku rządził przypadek, nie brakowało też lekkomyślności i nieodpowiedzialności. Pozwany bardzo łatwo nawiązał kontakty z inną kobietą, po czym wrócił do powódki, kontynuując z nią relację. Istotną sferą, która łączyła strony, była sfera seksualna. W życiu małżeńskim pozwany okazał się osobą nieodpowiedzialną, leniwą, skupioną na zaspokajaniu wyłącznie swoich potrzeb i przerzucającą na powódkę odpowiedzialność za wspólnotę małżeńską. Pozwany przyznał, że potrafił spać do dziesiątej, podczas gdy powódka była już w pracy. Nadużywał również alkoholu, prowadził rozrywkowy tryb życia, nie angażował się w prace domowe, oczekując, że tymi sprawami będzie zajmowała się powódka, sam pracował tylko dorywczo. Mnóstwo czasu spędzał przed komputerem, nie interesował

32 ASML, sygn. 333/2017/I instancja. 
się dzieckiem. Powódka wielokrotnie zarzucała mu, że nie dorósł do roli ojca, czemu pozwany nie zaprzeczał. Po rozstaniu stron zwolnił się z obowiązków wychowawczych wobec dziecka, nie nawiązując z nim żadnego kontaktu ${ }^{33}$.

Najbardziej widocznym przykładem syndromu Piotrusia Pana jest postawa reprezentowana przez pozwanego w sprawie toczącej się przed Sądem Metropolitalnym w Lublinie w 2016 r. Pozwany był młodszy od powódki o pięć lat. $W$ ocenie powódki różnica wieku nie była aż tak widoczna, choć nie zaprzecza, że wielokrotnie przyjmowała ona postawę opiekuńczo-matczyną wobec pozwanego. Dopiero kiedy po ślubie odkryła liczne zdrady i kłamstwa pozwanego, uświadomiła sobie, jak bardzo nieodpowiedzialnym i egoistycznym człowiekiem był pozwany. Pozwany był najstarszy z trojga rodzeństwa, przy czym dzieliła ich znaczna różnica wieku - brat był od niego młodszy o 10 lat, a siostra o 20. Matka pozwanego wskazała, że pozwanego przez długi czas traktowano jak jedynaka i rozpieszczano, a gdy pojawiło się rodzeństwo, był o nie zazdrosny i do dziś mają ze sobą słaby kontakt. Opisując syna, wskazała, że jest on egoistą, ma fantazję i zmyśla różne historie. Pozwany jeszcze w okresie przedślubnym nawiązał kontakt $\mathrm{z}$ inną kobietą i mimo zawarcia związku małżeńskiego nie przerwał tej relacji. Nie był jednak szczery wobec tej kobiety, nie powiedział jej również o powódce. Wyjeżdżając w podróż poślubną, zapewniał ją, że jedzie na wakacje z kolegami, a obrączka widoczna na przesłanym jej zdjęciu to założone dla żartów sreberko. Później nawiązał relację $\mathrm{z}$ trzecią kobietą. Żadna $\mathrm{z}$ nich nie wiedziała o istnieniu innych. Aby móc spotykać się z tymi kobietami, oszukiwał całą rodzinę i wymyślał absurdalne historie. Wzbudzał w powódce poczucie winy, twierdząc, że ta ogranicza jego wolność. Powódka podporządkowywała się jego licznym „wyjściom do kolegów”, wyręczała z obowiązków domowych, kiedy on "musiał zostać dłużej w pracy”. Dopiero gdy jedna z kobiet dowiedziała się o żonie pozwanego, jego kłamstwa wyszły na jaw. W rozmowie psychologicznej pozwany nie potrafił wytłumaczyć swoich zachowań, choć przerzucał odpowiedzialność za nie na swoją rodzinę, uważając, że nie otrzymał od niej odpowiedniego wsparcia. Pozwany nadal był bezkrytyczny wobec swojego zachowania. Z premedytacją prezentował instrumentalne traktowanie otoczenia i innych ludzi, brak krytycyzmu, skrajnie nieodpowiedzialną postawę. Był nastawiony na realizację

${ }^{33}$ ASML, sygn. 8009/2015/I instancja. 
własnych potrzeb, poszukiwał nowych przygód, podniet, stronił od poświęceń i tworzenia trwałych związków ${ }^{34}$.

\section{Zakończenie}

Przemiany społeczne ostatnich czasów w połączeniu z masowością kultury i jej konsumpcjonizmem stały się z pewnością dogodnym podłożem dla rozwoju syndromu Piotrusia Pana ${ }^{35}$. W świecie pełnym niedojrzałych egoistów część ludzi zachowuje się tak, jakby nie chciała dorosnąć i wziąć odpowiedzialności za swoje własne życie, nie mówiąc już o odpowiedzialności za świat, w którym żyją. Nie zastanawiając się nad przyszłością, nie traktują niczego i nikogo poważnie, oddając się własnym przyjemnościom. Trudno więc nie zgodzić się ze stwierdzeniem, że „wiek XX był stuleciem, w którym tragiczne zwycięstwo odniosła niedojrzałość; słowem, był wiekiem Piotrusia Pana" ${ }^{36}$. I nic nie wskazuje na to, żeby przyszłość w tym aspekcie miała się zmienić.

Wydaje się więc dziś, że niejeden „współczesny mężczyzna jest niedojrzałym, bujającym w obłokach chłopcem, który wybiera się na trzymiesięczną wyprawę w góry, pije, stracił pracę, ma kochankę i liczy, że ten problem jakoś sam się rozwiąże, jest uroczy, ale nie można na niego liczyć" ${ }^{\prime \prime}$. I chociaż nie ma nic złego w odczuwaniu niekiedy chęci przyłączenia się do Piotrusia Pana ${ }^{38}$, to jednak wycieczka do jego świata na dłużej może powodować tylko negatywne konsekwencje w rzeczywistym świecie, w którym człowiek funkcjonuje na co dzień.

Osoba dotknięta syndromem Piotrusia Pana nie jest zdolna do budowania wspólnoty małżeńskiej, dążenia do dobra potomstwa, poświęceń, wzięcia odpowiedzialności materialnej za założoną rodzinę, nie traktuje małżeństwa jako trwałego i dozgonnego przymierza. Nie jest również

34 ASML, sygn. 279/2016/I instancja.

35 Zob. A. Skorupa, Wieczni chłopcy i wieczne dziewczynki - refleksje o syndromie Piotrusia Pana u alpinistów, w: Człowiek wobec gór - perspektywa psychologiczna, filozoficzna i kulturoznawcza, red. R. Kulik, A. Skorupa, Wrocław 2010, s. 43.

36 F.M. Cataluccio, Niedojrzałość. Choroba naszych czasów, Kraków 2006, s. 11.

37 W. Eichelberger w rozmowie z R. Dziurdzikowską, Mężczyzna też człowiek, Warszawa 2003, s. 29.

38 Zob. D. Kiley, Syndrom Piotrusia Pana..., s. 29. 
zdolna do podjęcia i wypełnienia istotnych obowiązków małżeńskich, ponieważ stopień jej dojrzałości nie jest wystarczający, nawet pomimo osiągnięcia odpowiedniego wieku. Żyjąc beztrosko, to Piotruś Pan potrzebuje opieki i pełnej akceptacji innej osoby, ale bez stawiania mu wymagań.

Jak wskazuje praktyka Sądu Metropolitalnego w Lublinie, syndrom Piotrusia Pana jako przyczyna nieważności małżeństwa nie jest już tylko teoretyczną podstawą, a coraz częściej pojawiającym się problemem. Może on dotyczyć zarówno mężczyzn, jak i kobiet. Jeszcze do niedawna biegli sądowi właściwie nie posługiwali się tym terminem, opisując u takiej osoby jedynie szeroko pojętą niedojrzałość osobowościową, emocjonalną. W ostatnich latach coraz częściej używają oni jednak pojęcia syndromu Piotrusia Pana jako określenia szczególnego rodzaju niedojrzałości, która uniezdalnia nupturientów do ważnego zawarcia małżeństwa.

\section{Bibliografia}

\section{Źródła}

\section{Dokumenty Kościoła}

Codex Iuris Canonici auctoritate Ioannis Pauli PP. II promulgatus (25.01.1983 r.), AAS 75(1983), pars II, s. 1-317. Kodeks prawa kanonicznego, przekład polski zatwierdzony przez Konferencję Episkopatu, Poznań 1984.

\section{Źródła archiwalne}

Archiwum Sądu Metropolitalnego Lubelskiego, sygn. 8009/2015/I instancja; 8069/2015/I instancja; 279/2016/I instancja; 333/2017/I instancja.

\section{Literatura}

Badinter E., XY tożsamość mężczyzny, Warszawa 1993.

Braun-Gałkowska M., Psychologia domowa, Lublin 2008.

Bzymek A., Piotrusia Pana droga do ojca, w: Oblicza teorii i praktyki oświatowo-wychowawczej w czasie i przestrzeni, red. T. Maliszewski, J. Żerko, Gdańsk 2014.

Cataluccio F.M., Niedojrzałość. Choroba naszych czasów, Kraków 2006.

Góralski W., Dobro małżonków a istotne obowiązki matżeńskie, Warszawa 2010.

Góralski W., Kanoniczna zgoda małżeńska, Gdańsk 1991.

Kargul J., „Piotruś Pan” $i$ „Wieczna Dziewczynka” - w kalejdoskopie odraczania dorostości, Edukacja Dorosłych 2017, nr 1. 
Kiley D., Syndrom Piotrusia Pana. O nigdy nie dojrzewających mężczyznach, Warszawa 1993.

Mazur J., Oblicze fenomenu kidults, Tarnowskie Studia Teologiczne 2016, t. 35, nr 2.

Miłuński Z., Piotruś Pan i jego szpan, Charaktery 2006, nr 10.

Oleś P., Psychologia człowieka dorosłego, Warszawa 2011.

Paździor S., Przyczyny psychiczne niezdolności osoby do zawarcia małżeństwa w świetle kan. 1095 n. 3, Lublin 2009.

Pospiszyl K., O miłości ojcowskiej, Warszawa 1976.

Skorupa A., Wieczni chłopcy i wieczne dziewczynki - refleksje o syndromie Piotrusia

Pana u alpinistów, w: Człowiek wobec gór - perspektywa psychologiczna, filozoficzna

i kulturoznawcza, red. R. Kulik, A. Skorupa, Wrocław 2010.

Sztychmiler R., Istotne obowiązki małżeńskie, Warszawa 1997.

Sztychmiler R., Istotne obowiązki mał̇̇enskie w Kodeksie Prawa Kanonicznego z 1983 roku, Roczniki Nauk Prawnych 1997, t. 7.

Sztychmiler R., Obowiązki matżeńskie, Warszawa 1999.

W. Eichelberger w rozmowie z R. Dziurdzikowską, Mężczyzna też człowiek, Warszawa 2003.

Wnuk M., Wposzukiwaniu „dorosłości”, Dyskursy Młodych Andragogów 2007, nr 8.

\section{Streszczenie}

Osoba dotknięta syndromem Piotrusia Pana może bardzo dobrze radzić sobie na polu zawodowym, piąć się po szczeblach kariery, być osobą towarzyską i lubianą, a więc z pozoru być dobrym mężem lub żoną, ale realizując tylko nieistotne z prawnego punktu widzenia obowiązki małżeńskie, nadal będzie niezdolna do ważnego zawarcia małżeństwa. Do istotnych obowiązków małżeńskich należy zaś zaliczyć te, które warunkują realizację bonum prolis i bonum coniugum. Piotruś Pan nie jest zdolny do budowania wspólnoty małżeńskiej, dążenia do dobra potomstwa, poświęceń, wzięcia odpowiedzialności materialnej za założoną rodzinę, nie traktuje małżeństwa jako trwałego i dozgonnego przymierza. Osoba taka nie jest zdolna do podjęcia i wypełnienia istotnych obowiązków małżeńskich, ponieważ stopień jej dojrzałości okazuje się niewystarczający, nawet pomimo osiągnięcia odpowiedniego wieku. Żyjąc beztrosko, Piotruś Pan potrzebuje opieki i pełnej akceptacji innej osoby, ale bez stawiania mu wymagań.

Słowa kluczowe: syndrom Piotrusia Pana, dorosłość, dojrzałość, obowiązki małżeńskie, dobro potomstwa, dobro małżonków, niezdolność do małżeństwa, zaburzenia osobowości, proces o stwierdzenie nieważności małżeństwa 


\section{PETER PAN SYNDROME AS A CAUSE OF MENTAL INABILITY TO MARRIAGE IN THE PRACTICE OF THE METROPOLITAN COURT IN LUBLIN}

\section{Sum mary}

A person affected by the Peter Pan syndrome can do very well in the professional life by climbing up the career ladder, being a well-liked person, and thus becoming a seemingly good husband or wife. However, when fulfilling merely the marital obligations that are legally insignificant, he or she will still be unable to conclude a valid marriage. Essential marital obligations include those that determine the implementation of bonum prolis and bonum coniugum. A Peter Pan is not able to build a marital community, strive for the good of the offspring, make sacrifices or take material responsibility for the established family. Such a person does not treat marriage as a permanent and undying covenant, nor is able to face and fulfill important marital duties because its maturity is not adequate, despite being of proper age. While living carefree, it is Peter Pan who needs care and full acceptance of another person, yet with no demands.

Key words: Peter Pan Syndrome, adulthood, maturity, marital duties, welfare of offspring, welfare of spouses, inability to marry, personality disorder, marriage annulment process

\section{СИНДРОМ ПИТЕРА ПЭНА КАК ПСИХОЛОГИЧЕСКАЯ ПРИЧИНА НЕСПОСОБНОСТИ ВСТУПЛЕНИЯ В БРАК В ПРАКТИКЕ МИТРОПОЛИТАЛЬНОГО СУДА В ЛЮБЛИНЕ}

\section{Резюме}

Человек, у которого синдромом Питера Пэна, может очень хорошо работать в профессиональной сфере, подниматься по карьерной лестнице, быть общительным и хорошо восприниматься в обществе и, таким образом, казаться хорошим мужем или женой, но выполняя только юридически незначительные брачные обязательства, он все равно будет не в состоянии действительным образом вступить в брак. Однако, основные брачные обязательства включают в себя те, которые определяют реализацию bonum prolis и bonum coniugum. Питер Пэн не способен созидать семейную общину, стремиться к благу потомства, жертвовать собой, брать на себя материальную ответственность за созданную семью, он не рассматривает брак как постоянный и пожизненный завет. Такой человек не может взять на себя и выполнять существенные обязательства брака, потому что степень его 
зрелости недостаточна, даже несмотря на достижение соответствующего возраста. Живя беззаботно, Питер Пэн нуждается в заботе и полном принятии другим человеком, но без предъявления к нему требований.

Ключевые слова: синдромом Питера Пэна, совершеннолетие, зрелость, существенные обязательства брака, благо потомства, благо супругов, неспособность вступить в брак, расстройства личности, судебный процесс объявления брака недействительным 
